\title{
Lymphoepithelioma-like carcinoma of the lung: a rare case report and review of the literature
}

\author{
Ali \\ FIRINCIOĞLULARI ${ }^{1}(I D)$ \\ Berna AKINCI \\ ÖZYÜREK ${ }^{1}$ (ID) \\ Yurdanur ERDOĞAN ${ }^{\mathbf{1}}($ ID) \\ Funda iNCEKARA ${ }^{2}(\mid \mathrm{D})$ \\ Emre YILMAZ $^{2}$ (ID) \\ Hatice Esra \\ ÖZAYDIN $^{3}(I D)$
}

${ }^{1}$ Clinic of Chest Diseases, Ankara Ataturk Chest Diseases and Chest Surgery Training and Research Hospital, Ankara, Turkey

${ }^{1}$ Ankara Atatürk Gögüus Hastalıkları ve Göğüs Cerrahisi Eğitim ve Araştırma Hastanesi, Gögüus Hastalıkları Kliniği, Ankara, Türkiye

${ }^{2}$ Clinic of Thoracic Surgery, Ankara Ataturk Chest Diseases and Chest Surgery Training and Research Hospital, Ankara, Turkey

${ }^{2}$ Ankara Atatürk Gögüs Hastalıkları ve Göğüs Cerrahisi Eğitim ve Araştırma Hastanesi, Gögüs Cerrahisi Kliniği, Ankara, Türkiye

${ }^{3}$ Clinic of Pathology, Ankara Ataturk Chest Diseases and Chest Surgery Training and Research Hospital, Ankara, Turkey

3 Ankara Atatürk Göğüs Hastalıkları ve Gögüs Cerrahisi Eğitim ve Araştırma Hastanesi, Patoloji Kliniği, Ankara, Türkiye
Cite this article as: Fırıncıoğluları A, Akıncı Özyürek B, Erdoğan Y, Incekara F, Yılmaz E, Özaydın HE. Lymphoepithelioma-like carcinoma of the lung: a rare case report and review of the literature. Tuberk Toraks 2020;68(4):453-457.

Yazışma Adresi (Address for Correspondence)

\section{Dr. Ali FIRINCIOĞLULARI}

Ankara Atatürk Göğüs Hastalıkları ve

Göğüs Cerrahisi Eğitim ve Araştırma Hastanesi, Göğüs Hastalıkları Kliniği,

ANKARA - TÜRKIYE

e-mail: alifirincioglu@yahoo.com

\footnotetext{
CCopyright 2020 by Tuberculosis and Thorax.
}

Available on-line at www.tuberktoraks.org.com

\begin{abstract}
Lymphoepithelioma-like carcinoma of the lung: a rare case report and review of the literature

Lymphoepithelioma-like carcinoma (LELC), is a rare type of cancer and typically occurs in pharyngeal and foregut-derivative organs, Including the salivary glands, thymus, stomach and liver (1). Pulmonary LELC typically affects the young and non-smoking population, and is associated with Ebstein-Barr virus (EBV) infection $(1,2)$. We present an rare case with a pulmonary mass on CT scan of the thorax, which was subsequently proved as a LELC of the lung and a brief review of the relevant literature.

The patient is a 51-year old man, presented with shorthness of breath and cough for 1 months. Chest x-ray was normal (Figure 1). Chest CT scan showed a 30-25 mm heterogeneously enhanced mass lesion with well defined margin, In the left lower lobe of the lung (Figure 2). Bronchoscopy showed no endobronchial lesion. After the PET-CT, the patient was staged as cT2aN1MO (Stage 2B) (Figure 3). He received video-assisted thoracoscopic surgery of left lower lobe of lung and mediastinal lymph nodes dissection (Figure 4,5). His Ebv-Dna is Positive in blood tests. The pathology, immunohistochemical staining, and in situ hybridization results confirmed LELC of lung (Figure 6). Using in situ hybridization with exhibition of abundant EBVencoded small nuclear RNA, in the majority of tumor cells is done. He received 4 cycles of induction chemotherapy with cysplatine and vinoralbine. The patient was discharged from hospital with close follow-up. No recurrence has been detected so far.
\end{abstract}


Primary pulmonary LELC is a rare malignant tumor which accounts for only $0.9 \%$ of all primary lung cancer (1,2). Previous studies have demonstrated that pulmonary LELC is strongly associated with EBV infection (1,2). The majority of pulmonary LELC patients receive complete resection, as well as chemotherapy and radiotherapy based on their clinical stage $(1,2)$. Comparing to other nonsmall cell cancer (NSCLC), pulmonary LELC is more sensitive to chemotherapy and radiotherapy $(1,2)$

LELC of lung may be mistaken histopathologically for metastatic nasopharyngeal carcinoma or lymphoma. Its association with latent EBV infection have major implications for diagnosis and treatment. We present this case, because, its an unusual case with a pulmonary mass of the thorax, which was proved as a LELC of the lung.

Key words: Lymphoepithelioma-like carcinoma (LELC); Ebstein-Barr virus (EBV); NPC (Nasopharyngeal Carcinoma); cytokeratin (CK), Thorax CT; PET-CT

\section{ÖZ}

\section{Lenfoepitelyoma benzeri akciğer karsinomu: olgu sunumu ve literatürün incelenmesi}

Lenfoepitelyoma benzeri karsinom (LELC), nadir görülen bir kanser türüdür ve tipik olarak akciğer, tükürük bezleri, timus, mide ve karaciğer dahil olmak üzere birçok organda görülür (1). Pulmoner LELC tipik olarak genç ve sigara içmeyen popülasyonu etkiler ve Ebstein-Barr virüsü (EBV) enfeksiyonu ile ilişkilidir (1). Toraks BT incelemesinde pulmoner kitle bulunan ve patolojik olarak akciğerin Lenfoepitelyoma benzeri akciğer karsinomu tanısı konan nadir bir olguyu sunuyoruz.

51 yaşındaki erkek hasta kliniğimize, 1 aylık bir nefes darlı̆̆ı ve öksürük şikayeti ile başvurdu. Hastanın çekilen akciğer filmi normal idi (Figür 1). Çekilen Akciğer Toraks BT'sinde, akciğerin sol alt lobunda, sınırları olan yaklaşık 30 x 25 mm çapında heterojen bir kitle lezyonu mevcuttu (Figür 2). Hastaya yapılan Fiberoptik Bronkoskopi işlemi sonucunda endobronşiyal lezyon görülmedi. Çekilen PETCT'den sonra, hasta CT2aN1MO (Evre 2B) olarak evrelendi (Figür 3). Hastaya video yardımlı torakoskopik cerrahi (VATS) uygulandı. Hastaya akciğer sol alt lob ve mediastinal lenf nodu diseksiyonu yapıldı (Figür 4,5). Hastanın bakılan kan testlerinde, EBV-DNA pozitif saptandı. Patoloji sonucu, immunohistokimyasal boyama ve in situ hibridizasyon sonuçları ile akciğer LELC'mu tanısı doğrulandı. Immunohistokimyasal boyamada boyamada, akciğerin LELC'sinde hemen hemen her zaman pozitif olan bir belirteç olan sitokeratin (CK) pozitif saptandı. In stu hibridizasyon yöntemi ile, çok sayıda EBV kodlu küçük nükleer RNA'lar ve tümör hücrelerinin çoğunluğu gösterildi (Figür 6). Hasta yakından takip edilmek üzere önerilerle taburcu edildi. Hastaya 4 kür Sisplatin ve Vinoralbin indükksiyon kemoterapisi verildi. Hastada şimdiye kadar herhangi bir nükse rastlanılmadı.

Primer pulmoner LELC, tüm primer akciğer kanserinin sadece \%0.9'unu oluşturan nadir bir malign tümördür $(1,2)$. Yapılan araştırmalar sonucunda, pulmoner LELC'nin EBV enfeksiyonu ile anlamlı bir şekilde ilişkili olduğu gösterilmiştir (1). Pulmoner LELC hastalarının çoğunda, yapılan klinik araştırmalara göre kemoterapi ve radyoterapinin yanı sıra, tam rezeksiyondan tama yakın kür sağlanmıştır $(1,2)$. Diğer küçük hücre dışı akciğer kanserlerine (KHDAK) kıyasla, pulmoner LELC kemoterapi ve radyoterapiye daha duyarlıdır (1,2).

Akciğer LELC'mu metastatik nazofaringeal karsinom veya lenfoma tanıları ile histopatolojik olarak karışabilir veya yanlış tanı konulabilir. Latent EBV enfeksiyonu ile ilişkisi tanı ve tedavisi için önem taşımaktadır. Torasik kitle lezyonlarında, nadir olarak görülen, akciğer LELC'i tanısı alan nadir bir olguyu sunuyoruz.

Anahtar kelimeler: Lenfo-Epitelyoma benzeri akciğer karsinomu (LELC); Ebstein-Barr virus (EBV); küçük hücre dışı akciğer kanseri (KHDAK)

\section{INTRODUCTION}

Primary lymphoepithelioma-like carcinoma (LELC) is a rareform of lung cancer. Primary Lymphoepitheliomalike carcinoma (LELC) of the lung, which is a subtype of non-small cell lung cancer(NSCLC) was first studied in 1987, by Begin et al. (1). In the past two decades, there have been just more than 150 cases reported in the literature (2). Histologically, it is indistinguishable from undifferentiated nasopharyngeal carcinoma. The carcinogenic role of latent EpsteinBarr virus infection in causing LELC of the lung has been evident almost exclusively in Asians compared with Caucasians (2). Pulmonary LELC typically affects the young and non-smoking population, and is associated with Ebstein-Barr virus (EBV) infection $(3,4)$. EBV infection was detected in most of the reported cases, most of which were East Asians. Among the reported cases, more than half were in early resectable stages (I or II) and there was a tendency for peribronchovascular spread with vascular encasement in advanced diseases (4). The mainstay of treatment for early-stage disease is curative surgical resection, whereas multimodality treatment (surgery, chemotherapy, radiotherapy) has been adopted in advanced or metastatic diseases. The overall survival is more favorable in LELC of the lung compared with non-LELC type of non-small cell lung carcinoma.

\section{CASE REPORT}

The patient is a 51-year old Turkish man, presented with shortness of breath and mild cough for 1 months. He has no chronic disease. Chest x-ray was 
normal (Figure 1). Chest CT scan showed a $30 \times 25$ $\mathrm{mm}$ heterogeneously enhanced mass lesion with well defined margin and lobulated contour, in the left lower lobe of the lung (Figure 2). Bronchoscopy showed no endobronchial lesion. Head and neck CT scan and nasopharyngeal fiberoscopy were performed and no obvious tumor was found. After the PET-CT, the patient was staged as CT2aN1M0 (Stage 2B), (Figure 3). He received video-assisted thoraco-

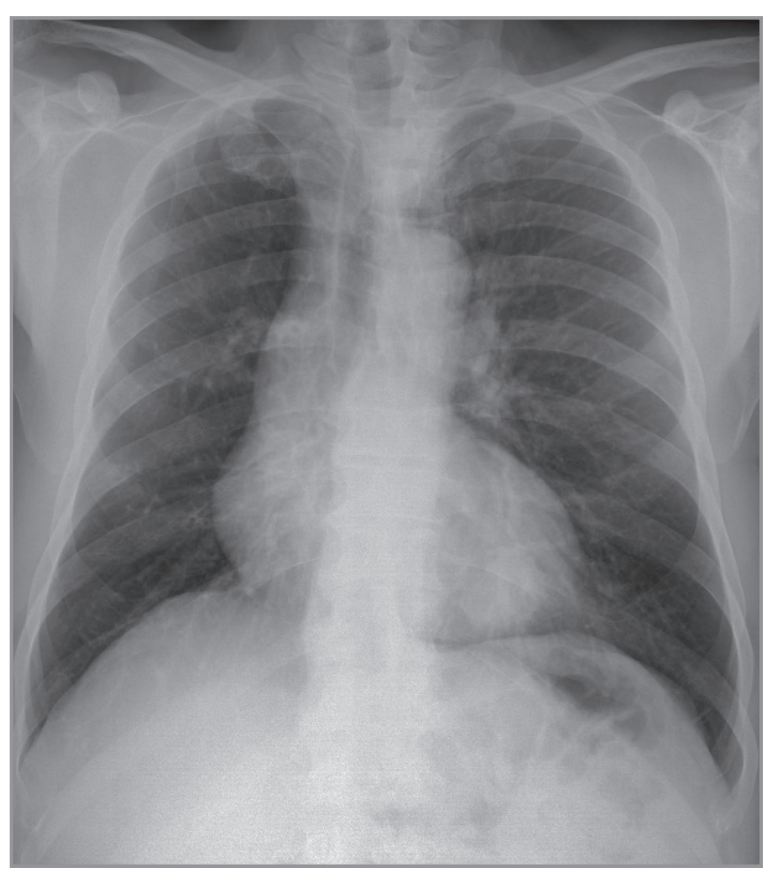

Figure 1. Patient's postero-anterior lung graphy, before surgery: Normal Lung graphy signs.

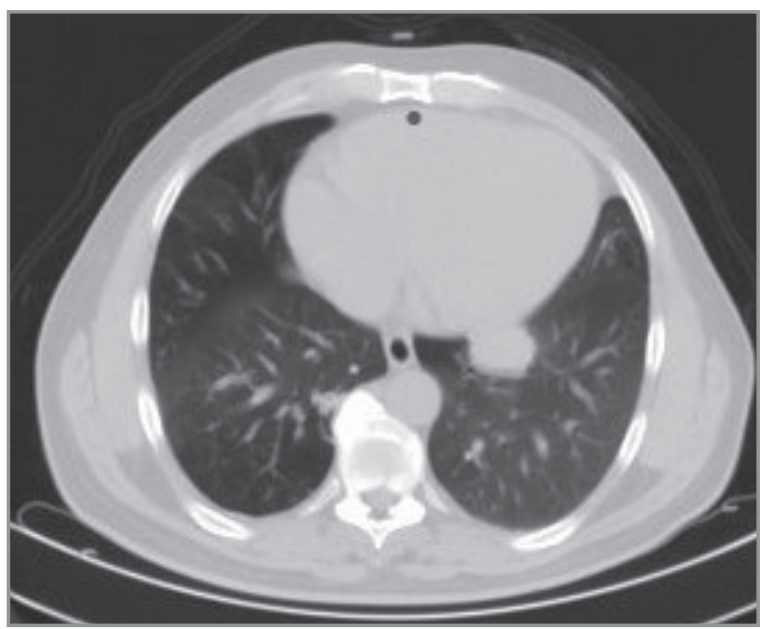

Figure 2. Patient's Thorax CT before surgery: $3 \mathrm{~cm}$ mass, in the left lower lobe antero-basal segment on Thorax CT. scopic surgery, of left lower lobe of the lung and mediastinal lymph nodes dissection (Figure 4,5). His Ebv-Dna is Positive in blood tests. The pathology, immunohistochemical staining (Figure 6) and in situ hybridization results confirmed LELC of the lung. Using in situ hybridization with exhibition of abundant EBV-encoded small nuclear RNA, in the majority of tumor cells is done. Immunohistochemical staining was positive for cytokeratin (CK), a marker which was almost always positive in LELC of lung. He was discharged 10 days after the operation. He received 4 cycles of induction chemotherapy with

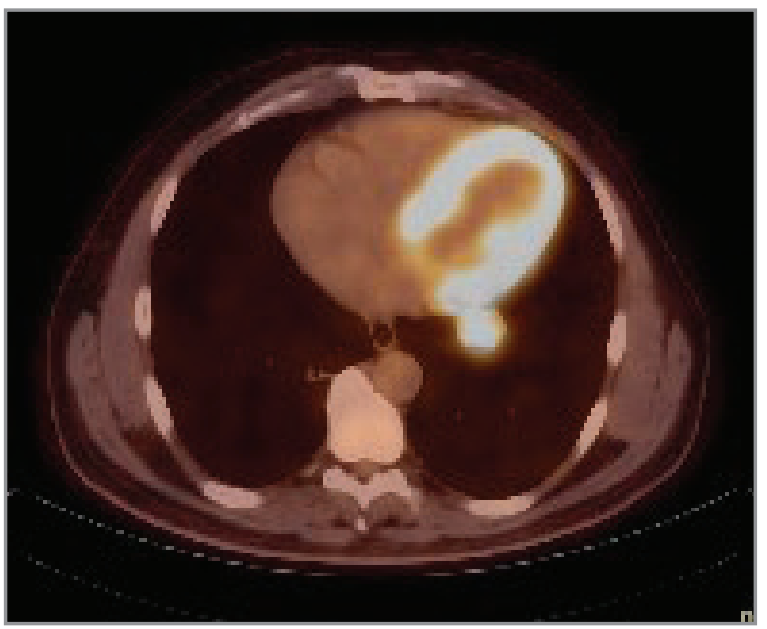

Figure 3. Pet-Ct scan before surgery: $3 \mathrm{~cm}$ mass in the left lower lobe antero-basal segment (SUVmax 7.5) on preoperative PET-CT.

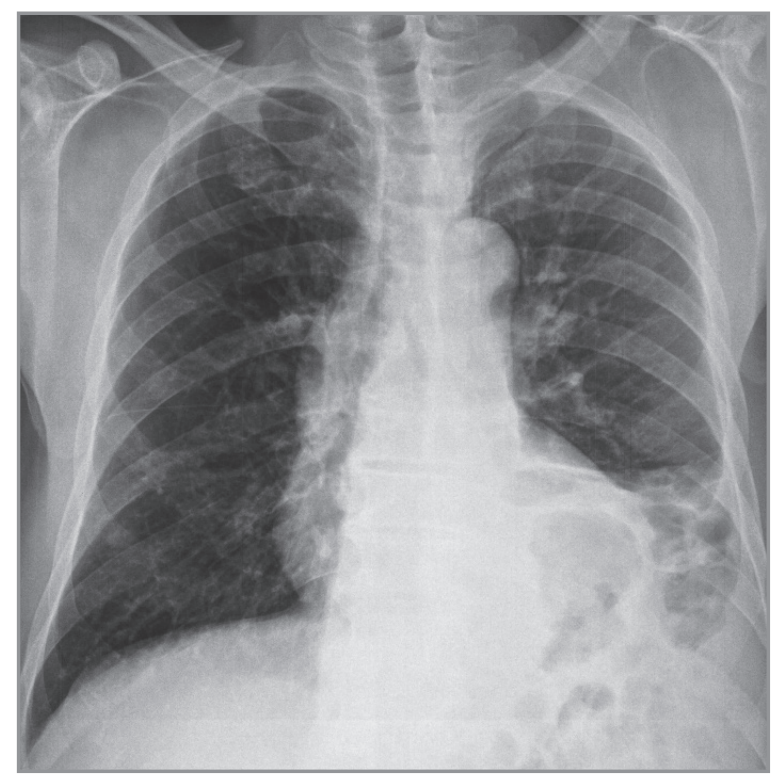

Figure 4. Patient's postero-anterior lung graphy, after surgery: Left lower zone atelectasis, on lung graphy. 


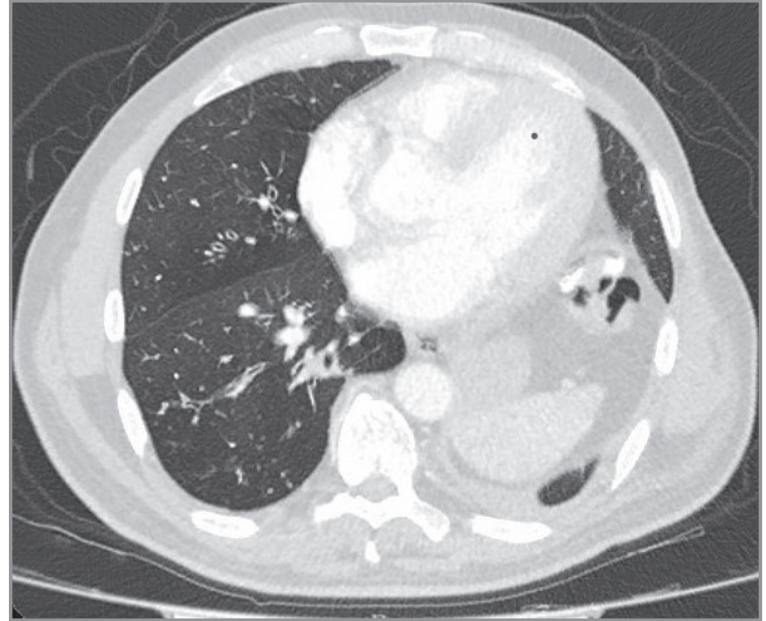

Figure 5. Patient's Thorax CT after surgery: Patient's Thorax $\mathrm{CT}$,after left lower lobectomy.

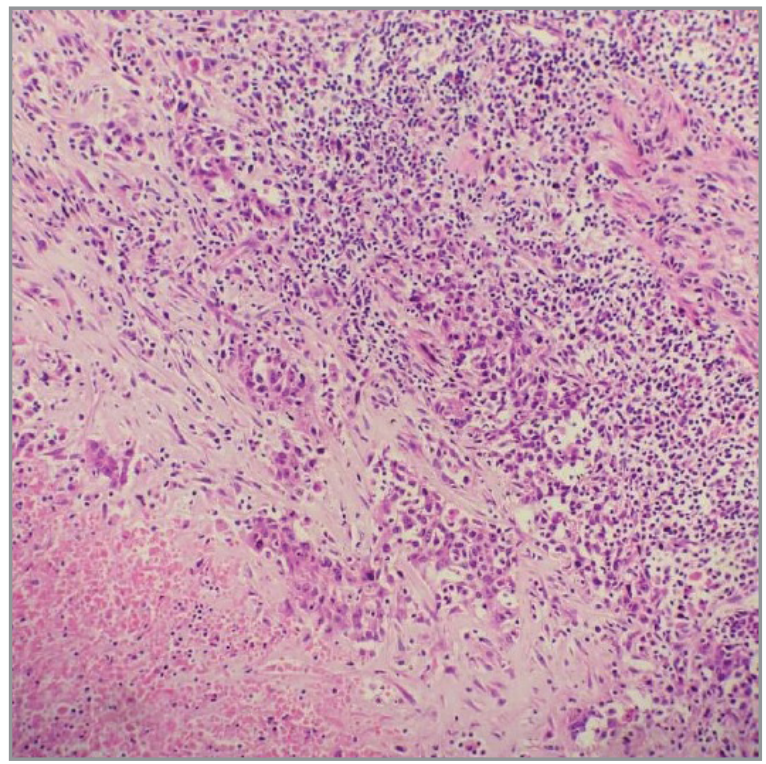

Figure 6. Hematoxylin and Eosin-stained cell block section shows syncytial tumor cells with Heavily infiltrating lymphocytes in the background, vesicular nuclei, and prominent nucleoli (original magnification $\times 200$ ).

cysplatine and vinoralbine. The patient had no postoperative complication and was discharged with the advice of chemotherapy. No recurrence has been detected so far.

\section{DISCUSSION}

Primary pulmonary LELC is a rare malignant tumor which accounts for only $0.9 \%$ of all primary lung cancer $(1,2)$ and only represents $0.4 \%$ of NSCLC $(3)$. Previous studies have demonstrated that pulmonary
LELC is strongly associated with EBV infection (1).It mostly affects Asians, especially the Chinese population, in comparison to Caucasians (1). LELC appears in organs such as the nasopharynx, stomach, lung, salivary gland and thymus, all of which originate from the foregut. In the localisations of these regions, LELC was reported to be associated with EBV infection (4-5). However, no association with EBV infection has been found for the skin, vagina, cervix, and bladder involvements, which are seen less frequently $(6,7)$. According to the immunohistochemical and molecular findings obtained from some microbiological studies, EBV-induced hyperplasia and premalignant lesions result from epithelial proliferation occurring due to the interaction between the virus and CD21 receptor on the surface of B lymphocytes (8). A high incidence of systemic metastases can be seen in cases with LELC of the lung. These metastases are prominently more chemosensitive compared to other non-small cell lung malignancies (9). Nasopharyngeal LELC is a highly radiosensitive tumour and a number of current studies have suggested that it is also chemosensitive (9). For advanced pulmonary LELC, platinum-based chemotherapy is regarded as the first line treatment. Adjuvant chemotherapy has been previously identified to markedly improve the prognosis for patients with stage IIIA LELC who underwent complete resection (10). Adjuvant radiotherapy and chemotherapy provide advantages for operable patients (11). However, for LELC of the lung, the success of radiotherapy and chemotherapy in treatment is unclear. Chemotherapy, radiotherapy or a combination of these two techniques can be used for inoperable cases. The majority of pulmonary LELC patients receive complete resection, as well as chemotherapy and radiotherapy based on their clinical stage $(12,13)$. Comparing to other non-small cell cancer (NSCLC), pulmonary LELC is more sensitive to chemotherapy and radiotherapy, which is similar to EBV associated NPC(Nasopharyngeal Carcinoma). Han et al. asserted that the overall survival rate is more favorable in LELC of the lung compared with non-LELC type of non-small cell lung carcinoma; furthermore, it was found that tumor recurrence and necrosis were poor prognostic factors for survival (14). However, other factors inherent to the nature of the carcinoma may play a part in its relatively good prognosis. The presence of abundant CD8-positive cytotoxic T lymphocytes adjacent to LELC cells and the underexpression of p53 and c-erb B-2 oncoproteins in tumor cells 
have been postulated to account for the better prognosis in LELC of the lung (15).

\section{CONCLUSION}

Pulmonary LELC are similar to those of bronchogenic carcinomas in the majority of cases. LELC of lung may be mistaken histopathologically for metastatic nasopharyngeal carcinoma or lymphoma. Its association with latent EBV infection have major implications for diagnosis and treatment. If the cases of LELC are clinically operable, then surgical resection procedures should be performed. We present this case, because, it's an unusual case with a pulmonary mass of the thorax, which was proved as a LELC of the lung.

\section{CONFLICT of INTEREST}

The authors reported no conflict of interest related to this article.

\section{AUTHORSHIP CONTRIBUTIONS}

Concept/Design: AF

Analysis/Interpretation: AF

Data Acquisition: AF

Writing: AF

Critical Revision: AF, BAÖ

Final Approval: AF, BAÖ

\section{REFERENCES}

1. Begin LR, Eskandari J, Joncas J, Panasci L. EpsteinBarr virus related lymphoepithelioma-like carcinoma of lung. I Surg Oncol 1987; 36: 280-3.

2. Ho JC, Wong MP, Lam WK. Lymphoepithelioma-like carcinoma of the lung. Respirology 2006; 11: 539-45.

3. Mo Y, Shen J, Zhang Y, Zheng L, Gao F, Liu L,et al. Primary lymphoepithelioma-like carcinoma of the lung: distinct computed tomography. I Thorac Imaging 2014; 29(4): 246-51.

4. Chan JK, Hui PK, Tsang WY, Law CK, Ma CC, Yip TT, et al. Primary lymphoepithelioma-like carcinoma of the lung. A clinicopathologic study of 11 cases. Cancer 1995; 76: 413-22.
5. Oda K, Tamaru J, Takenouchi T, Mikata A, Nunomura M, Saitoh N, et al. Association of Epstein Barr virus gasric carcinoma with Ihymphoid stroma. Am I Pathol 1993; 143: 1063-74.

6. Land AC, Breer WA, Wick MR. Lymphoepithelioma like carcinoma of the skin with apparent origin in the epidermis: A pattern or an entity? A case report. Cancer 1999; 85: 884-90.

7. Weiss LM, Movahed LA, Butler AE, Swanson SA, Frierson $H F \mathrm{Jr}$, Cooper PH, et al. Analysis of lymphoepithelioma and lymphoepithelioma like carcinomas of different organs for Epstein Barr viral genomes by in situ hybridization. Am J Surg Pathol 1989; 13: 625-31.

8. Grinstein S, Preciado MV, Gattuso P, Chabay PA, Warren $W H$, De Matteo E, et al. Demonstration of Epstein-Barr virus in carcinomas of various sites. Cancer Res 2002; 62: 4876-8

9. Han AJ, Xiong M, Zong YS. Association of Epstein-Barr virus with lymphoepithelioma-like carcinoma of the lung in southern China. Am J Clin Pathol 2000: 114; 220-6.

10. Liang Y, Wang L, Zhu Y, Lin Y, Liu H, Rao H, et al. Primary pulmonary lymphoepithelioma-like carcinoma: Fifty-two patients with long-term follow-up. Cancer 2012; 118: 4748-58.

11. Anthony TCC, Peter MLT, Kwok CL, Wing YC, John HS, Chow MD, et al. Multimodality treatment of primary lymphoepithelioma like carcinoma of the lung. Cancer 1998; 83: 925-9.

12. Liang $R$, Chen $T X$, Wang $Z Q$, Jin $K W$, Zhang $L Y$, Yan $Q N$, et al. A retrospective analysis of the clinicopathological characteristics of large cell carcinoma of the lung. Exp Ther Med 2015; 9: 197-202.

13. Lin Z, Situ D, Chang X, Liang W, Zhao $M$, et al. Surgical treatment for primary pulmonary lymphoepithelioma-like carcinoma. Interact Cardiovasc Thorac Surg 2016; 23. 41-6.

14. Han AJ, Xiong $M, G u \quad Y Y$, Lin $S X$, Xiong $M$. Lymphoepithelioma-like carcinoma of the lung with a better prognosis: a clinicopathologic study of 32 cases. Am J Clin Pathol 2001; 115(6): 841-50.

15. Chang YL, Wu CT, Shih $J$, Lee YC. New aspects in clinicopathologic and oncogene studies of 23 pulmonary lymphoepithelioma-like carcinomas. Am I Surg Pathol 2002; 26: 715-23. 